\title{
Loss of Vector-Transmissibility by Maintaining Rice Ragged Stunt Virus in Rice Plants without Vector Transmission
}

\author{
Tetsuo MaOKA*, Toshihiro OMURA**, Jumanto Harjosudarmo***, \\ Tomio UsUGI*, Hiroyuki HIBINO** and Tsuneo TsuCHIZAKI ${ }^{\dagger}$
}

Key words: RRSV, vector, transmissibility,

Rice ragged stunt virus (RRSV) causes serious disease in South and Southeast Asian Countries and occurs also in China, Japan and Taiwan ${ }^{1,3}$. RRSV is transmitted in a persistent manner by the brown planthopper Nilaparvata lugens (Stal). The virus particles consist of polyhedral core ones approx. $50 \mathrm{~nm}$ in diameter to which are attached flat spikes about $20 \mathrm{~nm}$ wide and $10 \mathrm{~nm}$ high ${ }^{2}$. RRSV has 10 segments of double-stranded $\mathrm{RNA}^{7)}$ and several proteins ${ }^{2}$. In plant reovirus group, non-vector transmissible isolates have been obtained for leafhopper-borne wound tumor virus (WTV) ${ }^{\text {s) }}$ and rice dwarf virus $(\mathrm{RDV})^{5)}$ after maintaining the virus for many years in plants without leafhopper vector transmission. This paper reports loss of vector transmissibility of RRSV after maintaining it for 3 years in rice plants without planthopper vector transmission. Symptoms, particle structure, RNAs and proteins of the non-vector-transmissible isolate are also described.

In March 1981, seedlings of rice plants (Oriza sativa L. cv. Taitung Native 1) were inoculated with RRSV using viruliferous $N$. lugens. One infected seedling was selected and grown in a greenhouse. Three months after infection, tillers were divided from the selected plant and transplanted separately in pots. Every three months thereafter, tillers were divided from the vegetatively propagated plants and transplanted separately. After the first winter season was over, one plant was selected from a set of vegetatively propagated infected plants and used for vegetative propagation in the following year. The same cycle of selection and vegetative propagation was repeated for seven years. In March 1982, seedlings were similarly infected and the same cycle of selection and vegetative propagation was repeated on one selected plant for six years. On plants infected with RRSV in 1983, 1984, 1985, 1986 or 1987, the same cycle of selection and propagation was repeated for five, four, three, two or one years, respectively. In June 1988, seven sets of RRSV-infected plants maintained for one to seven years by vegetative propagation were used for virus transmission. A plant newly infected in 1988 served as the control.

The second or third-instar nymphs of the brown planthopper were fed for 2 days on each of three plants selected from each set of vegetatively propagated plants and then they were reared on healthy rice seedlings. Two weeks after the initiation of the acquisition feeding, rice seedlings were inoculated by one planthopper per seedling for 2 days. Inoculated seedlings were grown in a greenhouse. RRSV symptoms on inoculated seedlings were observed one month later. As shown in Table 1, vectortransmissibility of RRSV from vegetatively propagated RRSV-infected plants decreased with the advance of years after inoculation for the first two years and it was lost in the third year and thereafter. Percentage of transmission of RRSV by the colony of $N$. lugens used in this study was $45 \%$ in the first year, $37 \%$ in the third year and was $17-53 \%$ in the seventh year. The isolate maintained for 7 years in rice plants without vector transmission was designated as non-vector-transmissible (NT) isolate and used in the following experiments.

- Okinawa Branch of Tropical Agriculture Research Center, Maesato Ishigaki, Okinawa 907, Japan 支所

** National Agricultural Research Center, Tsukuba, Ibaraki 305, Japan＼cjkstart農研センター

*** Bogor Research Institute for Food Crops, Jalan Merdeka 99, Bogor, Indonesia

- Faculty of Agriculture, The University of Tokyo, Bunkyo-ku, Tokyo 113, Japan 
Table 1. Percentage of transmission by Nilaparvata lugens of RRSV that was maintained in rice plants for zero to seven years by vegetative propagation

\begin{tabular}{cccc}
\hline \hline Years & & Trials $^{\text {a) }}$ & \\
\hline & I & II & III \\
\hline 0 & 27 & 53 & 17 \\
1 & 19 & 61 & $-{ }^{\mathrm{b})}$ \\
2 & 2 & 0 & - \\
3 & 0 & - & - \\
4 & 0 & - & - \\
5 & 0 & 0 & 0 \\
6 & 0 & - & 0 \\
7 & 0 & 0 & 0 \\
\hline
\end{tabular}

a) 100 rice plants were inoculated by $N$. lugens.

b) Not tested.

1

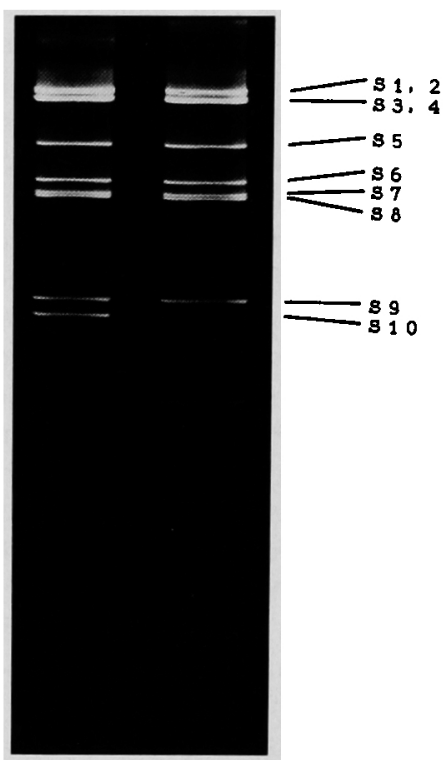

Fig. 1. Electrophoresis of the RNAs of non-vector-transmissible isolate and the original RRSV in a $10 \%$ polyacrylamide gel. Lane 1, the original RRSV; Lane 2, the non-vector-transmissible isolate.

NT isolate did not cause significant plant stunting as did the original RRSV. Galls and ragged or twisted leaves appeared less frequently in plants having NT isolate than in plants infected with the original RRSV.

NT isolate was purified according to the method described by Omura et al. ${ }^{7)}$ Purified viral preparations were stained with $2 \%$ aqueous uranyl acetate (UA) and were observed under a Hitachi H7000 electron microscope. The particles were 50-55 nm in diameter with "spikes" on their surface. NT isolate was similar to the original RRSV in particle morphology.

Electrophoresis of protein components of purified virus was performed according to the method reported by Hagiwara et al. ${ }^{2)}$ except that proteins were dissolved by heating for $5 \mathrm{~min}$ at $100^{\circ} \mathrm{C}$ and the concentration of polyacrylamide gel was $12.5 \%$. No apparent difference was observed after the electrophoresis in the pattern of protein components between the original RRSV ${ }^{2}$ and NT isolate (data not shown). 
RNAs were extracted from purified preparation and electrophoresed according to the methods of Omura et al. ${ }^{\text {) }}$ Electrophoresis of RNAs of the original RRSV resolved 8 distinct bands (segment 1 to 10) (Fig. 1) as reported previously ${ }^{7}$. While two additional, fast-migrating bands were detected in NT isolate. The mol. wt. of the new bands estimated by regression analyses using the mol. wt. of the original RNAs $^{7)}$ were $0.44 \times 10^{6}$ and $0.08 \times 10^{6}$. The genome segment S10 $\left(0.85 \times 10^{6}\right)$ of NT isolate was stained weaker than the other bands of the isolate. Similar result was obtained in the isolate maintained for 5 years. The relationships between the two fast-migrating bands and the genome segment S10, and the lack of vector transmissibility need to be clarified.

The concentration of RRSV antigen in the leaves of the rice plants was compared between NT isolate and original RRSV by enzyme-linked immunosorbent assay (ELISA) ${ }^{4}$. The antigen concentration in plants having NT isolate was $1 / 2$ to $1 / 4$ of that in original RRSV-infected plants (data not shown).

$\mathrm{NT}$ isolate was different from the original RRSV in the genome composition and genome size. The appearance of fast-migrating bands and the reduction in quantity of the genome segment S10 suggest that the new segments may be derived from S10. In case of non-vector-transmissible strain of WTV, S5 which is related to vector transmissibility ${ }^{8}$ has deletion, demonstrating further that the translational product of S5 is associated with the vector transmissibility ${ }^{6}$. If this is the case for RRSV, the translational product of RRSV S10 can be associated with the transmissibility by planthoppers. Thus, we have added a new strain that will provide us information which would help us in understanding the RRSV transmissibility. Furthermore, this is the first incidence of a virus strain which has lost its transmissibility by planthopper vector.

\section{Literature cited}

1. Milne, R.G., Boccardo, G. and Ling, K.C. (1982). Rice ragged stunt virus. CMI/AAB Descriptions of Plant Viruses No. 248.

2. Hagiwara, K., Minobe, Y., Nozu, Y., Hibino, H., Kimura, I. and Omura, T. (1986). Component proteins and structure of rice ragged stunt virus. J. gen. Virol. $67:$ 1711-1715.

3. Hibino, H., Roechan, M., Sudarisman, S. and Tantera, D.M. (1977). A virus disease of rice (kerdil hampa) transmitted by brown planthopper, Nilaparvata lugens Stal, in Indonesia. Contr. Centr. Res. Inst. Agric. Bogor 35 : 1-15.

4. Hibino, H. and Kimura, I. (1982). Detection of rice ragged stunt virus in insect vectors by enzyme-linked immunosorbent assay. Phytopathology $72:$ 656-659.

5. Kimura, I. (1976). Loss of vector-transmissibility in an isolate of rice dwarf virus. Ann. Phytopath. Soc. Japan $42: 322-324$.

6. Nuss, D.L. and Summers, D. (1984). Variant dsRNAs associated with transmission-defective isolates of wound tumor virus represent terminally conserved remnants of genome segments. Virology 133: 276-288.

7. Omura, T., Minobe, Y., Kimura, I., Hibino, H., Tsuchizaki, T. and Saito, Y. (1983). Improved purification procedure and RNA segments of rice ragged stunt virus. Ann. Phytopath. Soc. Japan 49:670-675.

8. Reddy, D.V.R. and Black, L.M. (1974). Deletion mutations of the genome segments of wound tumor virus. Virology $61: 458-473$.

\section{和 文 摘 要}

眞岡哲夫・大村敏博・J. HARJOSUDARMO・宇杉富雄・日比野啓行・土㥓常男：イネラギッドスタントウイルスにおけ る昆虫伝搬性の赇失

イネラギッドスタントウイルスをイネに接種し,株分けによる増殖を 3 年以上繰り返したところ, 昆虫伝搬性が失か れた。昆虫非伝搬株はイネに萎縮を起こさず，イネ体内におけるウイルス漕度も伝搬株に比へ低かった。また，昆虫非 伝搬株の核酸の電気泳動では, 伝搬株にはみられない泳動度の速いバンドが新たに 2 本生じるとともに, S10フラグメ ントの量が減少した。このことから S10 フラグメントが昆虫伝搬性に関与している可能性が示唆された。

(Received July 30, 1992) 